
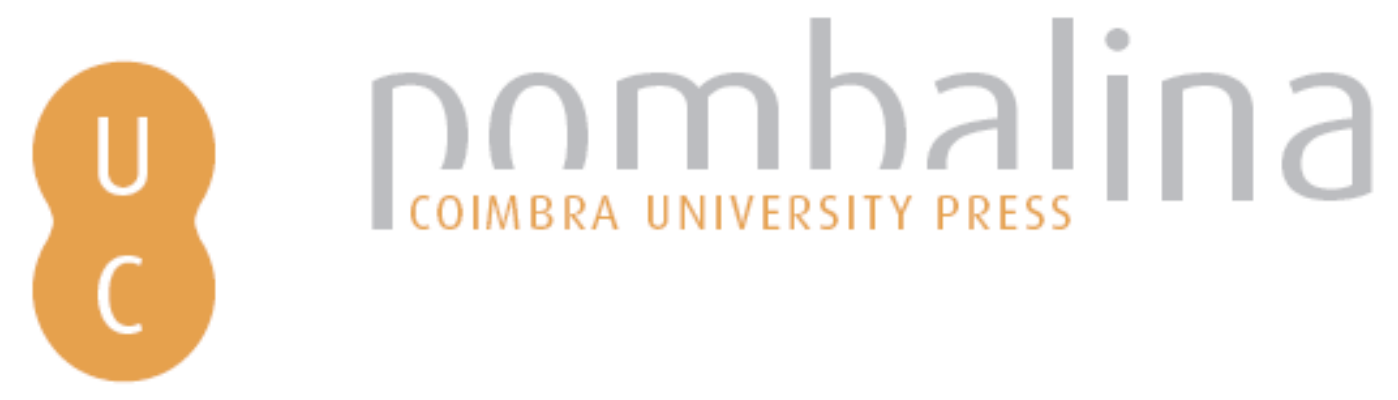

\title{
Vegetation fire management in strict nature reserves
}

Autor(es): $\quad$ Volokitina, Alexandra V.; Sofronova, Tatiana M.; Korets, Mikhail A.

Publicado por: Imprensa da Universidade de Coimbra

URL

persistente: URI:http://hdl.handle.net/10316.2/44685

DOI: $\quad$ DOI:https://doi.org/10.14195/978-989-26-16-506_168

Accessed : $\quad$ 26-Apr-2023 13:28:31

A navegação consulta e descarregamento dos títulos inseridos nas Bibliotecas Digitais UC Digitalis, UC Pombalina e UC Impactum, pressupõem a aceitação plena e sem reservas dos Termos e Condições de Uso destas Bibliotecas Digitais, disponíveis em https://digitalis.uc.pt/pt-pt/termos.

Conforme exposto nos referidos Termos e Condições de Uso, o descarregamento de títulos de acesso restrito requer uma licença válida de autorização devendo o utilizador aceder ao(s) documento(s) a partir de um endereço de IP da instituição detentora da supramencionada licença.

Ao utilizador é apenas permitido o descarregamento para uso pessoal, pelo que o emprego do(s) título(s) descarregado(s) para outro fim, designadamente comercial, carece de autorização do respetivo autor ou editor da obra.

Na medida em que todas as obras da UC Digitalis se encontram protegidas pelo Código do Direito de Autor e Direitos Conexos e demais legislação aplicável, toda a cópia, parcial ou total, deste documento, nos casos em que é legalmente admitida, deverá conter ou fazer-se acompanhar por este aviso.

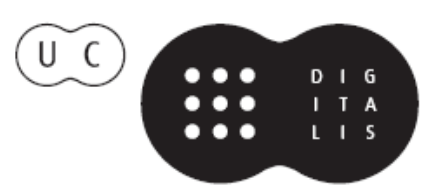




\section{ADVANCES IN}

\section{FOREST FIRE RESEARCH}

\section{8}

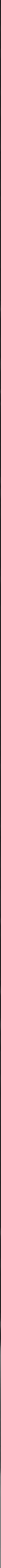


Short contribution - Fire Management

Vegetation fire management in strict nature reserves

\author{
Alexandra V. Volokitina ${ }^{1}$; Tatiana M. Sofronova ${ }^{2 *}$, Mikhail A. Korets ${ }^{1}$ \\ ${ }^{1}$ Sukachev Institute of Forest SB RAS, ul.Akademgorodok,50/28, Krasnoyarsk 660036, \\ Russia,\{volokit@ksc.krasn.ru,mik@ksc.krasn.ru\} \\ ${ }^{2}$ Astafiev Krasnoyarsk State Pedagogical University, ul. A. Lebedevoy,89, Krasnoyarsk 660049, Russia, \\ \{tmsofronova@gmail.com*\}
}

\begin{abstract}
The protected areas (PAs) are established to conserve biological diversity, to maintain nature complexes and objects in their natural condition. Strict nature reserves prevail in Russia by their total area. The whole nature complex is forever extracted from economic use in nature reserves. Here it is prohibited to pursue any activity which might disturb or damage the nature complexes. Even under the existing strict protection from anthropogenic ignition sources, vegetation fires do occur on their territory. Besides, lightnings - these natural ignition sources - are impossible to exclude. Since large destructive fires are impermissible in nature reserves, the latter especially need vegetation fire behavior prediction for fire management. Fire behavior prediction includes fire spread rate, development (from surface fire into crown or ground one) and effects. All this is necessary for taking optimal decisions on how to control each occurring fire and how to suppress it. The Sukachev Institute of Forest SB RAS has developed a technique of vegetation fire behavior prediction using vegetation fuel maps (VF maps).
\end{abstract}

Keywords: strict nature reserves, vegetation fire management, fire behavior prediction, vegetation fuel maps, identifier of primary fire carriers

\title{
1. Introduction
}

The protected areas (PAs) are established to conserve biological diversity, to maintain nature complexes and objects in their natural condition. Taking into account the special regime and status of the environmental conservation institutions there, various IUCN categories of PAs are distinguished: strict nature reserves or wilderness areas (including biosphere ones), national parks, habitat/ species management areas, natural monuments, etc. Strict nature reserves prevail in Russia by their total area.

Large destructive fires are impermissible todevelop in nature reserves. This issue can be resolved largely by improvement fire danger rating, fire behavior prediction and fire management. Vegetation fire management in nature reserves is quite possible on the basis of modern fundamnetal fire science elaborations which improve fire danger rating, prediction of an occurred fire depending upon weather conditions, and make it possible to control flame (or flameless) combustion spread over the area and to take optimal decisions on fire suppression.

\section{Background}

L.V. Kuleshov and V.N. Korotkov (2002) made a detailed analysis of wildfires in nature reserves of Russia. Fire dynamics was analyzed for the period from 1975 till 2000. Growth tendency was identified in the number of wildfires in nature reserves and in the number of nature reserves subject to burning in this period. What draws attention is the correlation of forest and non-forest areas. For instance, after 1990, burnt areas predominated in non-forest areas. This fact should be obligatory taken into account when developing the strategy of fire management in nature reserves. It should be noted that the US, Canada and Australia have developed guidelines for fire management on protected areas and that "similar tasks are urgent for Russia with its vast forested areas, high diversity of forest 
vegetation conditions and high forest fire danger" (Kuleshova, Korotkov, 2002).

By now, forest fire scientists of the Sukacev Institute of Forest SB RAS have developed ways to improve fire danger rating according to weather conditions and according to vegetation fuel (VF) complexes, predict burning intensity on a given vegetation plot as well as possible fire effects.

\section{Improvement of fire danger rating in nature reserves}

Two kinds of fire danger are defined in nature reserves: fire danger rating according to weather conditions and according to VF complexes. For fire danger rating according to weather conditions the following indices are used: the Nesterov Index with rough account of precipitation and the PV-1 Index with a more differentiated account of precipitation. Further improvement of the enumerated indices is realized in the index developed at the Sukachev Institute of Forest SB RAS. It takes into account humidity and hygroscpicity of the surface fuels and "works" under negative temperatures (Sofronov, Volokitina, Sofronova, 2008).

\section{Vegetation fire behavior prediction in nature reserves}

When studying fires in nature reserves they are often called forest fires. However, fires spread over non-forest areas with burnt areas larger over non-forest than forest areas. Therefore it would be better to call them vegetation fires. The term "fire management" should also be explained. This term is suggested to understand in a broad and in a narrow ways. In itsbroad meaning, it includes exclusion of anthropogenic causes of fire occurrence (fire preventive arrangement of the area), creation of favorable conditions for timely fire detection and fire suppression (airpatrol, a net of fire lookout posts, a road net), etc. In its narrow meaning, fire management should be understood as control over development of ocurring fires on the basis of their behavior and effects prediction. Methods of VF mapping and fire behavior prediction (including GIS) are developed (Volokitina, Sofronov, 2002; Volokitina, Korets, Sofronova, 2012; Korets, Volokitina, 2014, 2015). On their basis, in cooperation with the Eastern-Siberian Forest Inventory Institution an information database was created and VF maps were made for two different periods of a fire season in four nature reserves of Russia: Stolby (Krasnoyarsk krai), Sayano-Shushensky (Krasnoyarsk krai), Kuznetsky Alatau (Kemerovskaya oblst), and Ubsunurskaya kotlovina (The Republic of Tyva). Besides, pyrological characteristics of forest types was developed for the Baikalsky Nature Reserve and the Tunkinsky National Park (Sofronova, Sofronov, Volokitina, 2005; Sofronova, Volokitina, Sofronov, 2007).

\section{Vegetation fire management in nature reserves}

To manage vegetation fires in nature reserves, first of all, it is necessary to creat an information database containing VF maps. Since Russian nature reserves go through the first forest inventory type, it is quite possible to create the information database using the data of the previous forest inventory using the technique developed by the Sukachev Institute of Forest SB RAS for analysis of forest type schemes and their pyrological characteristic. If old forest inventory data are not relevant already and a new forest inventory is being planned then it would be better to create a new information database for making VF maps with more accurate pyrological characteristics on the basis of the Sukachev Institute identifier for primary fire carriers in the process of forest inventory.

Further, on the basis of a chosen fire spread model, a developed computer software is used to predict behavior of a specific fire: specific pyrological characteristics are introduced from the VF map as well as weather data on a given time. The software program calculates the surface fire edge spread in a given time periods. On the sites where a surface fire can develop into a crown or a ground one, the program shows this probability. Besides, the software reflects possible fire effects in forest stands depending upon the combustion intensity, tree species and mean tree stand dimeter in terms of tree 
mortality expressed in percent. Additionally, taking into account the length of a fire edge, the software calculates the necessary suppression forces for a given stage.

By now, the vegetation fire behavior prediction software has successfully gone through a retrospective performance test in plain conditions (the Chunsky Forest Office of the Krasnyarsky krai) and in mountain conditions (the Stolby Nature Reserve of the Krasnoyarsk krai).

\section{Conclusion}

Vegetation fire management is quite realistic in nature reserves of Russia. Most nature reserves have the necessary information database for their forest inventory is of a high forest inventory type. Nature reserves have their own weather stations and use automatic ones. The software for vegetation fire behavior prediction is pretty straightforward for the specialists of nature reserves to master. 